\title{
Dimensions of time and space in sociology*
}

\author{
J. Šubrt ${ }^{1}$, L.G. Titarenko ${ }^{2}$ \\ ${ }^{1}$ Charles University \\ U Křžěe, 8, Praha 5, 15800, Czech Republic \\ ${ }^{2}$ Belarusian State University \\ Prosp. Nezavisimosti, 4, Minsk, 220030, Belarus \\ (e-mail: Jiri.Subrt@ff.cuni.cz; larissa@bsu.by)
}

\begin{abstract}
Contemporary sociology has significantly changed the concept of space and time. According to Wallerstein, time and space represent a reality that sociology has long neglected. The situation is different in historical sciences, in which, as White states, the narrative approach prevails, and in historical sociology. The authors focus on time and space as 'frames' for the historically oriented explanation. Thus, time can be understood in different ways - as passing, duration, measure, moment appropriate for an action or change. Different forms of time represent different 'frames' for interpreting social events. Space is often interpreted in the relational perspective - as an order of relations formed by interacting subjects. The frame, in which we place an event, determines how we see and think about space and time. Reflections on time were significantly influenced by Braudel, who distinguished three levels of historical time. Today, the issue of space and time-space is considered by social geography, which provides some insights for sociology, as Giddens shows, especially when examining modernization and globalization. The sociological concept of time-space was developed by Wallerstein, who distinguished five types of space-time: episodic-geopolitical, conjunctural-ideological, structural, eternal, and transformative. These types of space-time provide different perspectives for the analysis of specific historical events. One of the reasons why Wallerstein places such an emphasis on space-time is that he believes that we are in the transformative time-space, which marks the end of the long structural spacetime of the world system. Therefore, we face opposing historical choices and have no certainty, except that every step we take will have serious consequences.
\end{abstract}

Key words: sociological theory; historical sociology; history; frames; time-space; development; cycles; modernization; globalization; Wallerstein; Giddens

Time and space represent important but still largely neglected dimensions of social reality in the sociological research, even though there is a long-standing tradition of efforts to grasp both within the sociological research perspective. This tradition includes thinkers of the $19^{\text {th }}$ and $20^{\text {th }}$ centuries, especially those who tried to capture the dynamics of the capitalist system (Marx, Weber, Durkheim). Works of Pitirim Sorokin [28] are still discussed in Russia $[1 ; 2 ; 3 ; 7 ; 8]$ as playing the key role in the time-space debates. In this paper, we focus on the historical-sociological perspective [9] as monitoring modernization.

Thus, Immanuel Wallerstein considered the past of social sciences to find out that for two centuries, there is an epistemological contradiction between

\footnotetext{
* (C) J. Šubrt, L.G. Titarenko, 2020

The article was submitted on 16.05.2020. The article was accepted on 30.08.2020.
} 
'universalists' and 'particularists', 'theorists' and 'empiricists', supporters of 'nomothetic' and 'idiographic' methods. In the late $19^{\text {th }}$ century, this conflict turned into a dispute about methods between two groups: one believed that social reality was determined by laws (nomothetic method) which could be discovered and put into words, while the other (ideographic method) did not believe in such laws existed for they would contradict the freedom of human will choose one's destiny. This dispute reflects contradiction between determinism and free will, between realism and nominalism. When asked, when and where this dispute took place, Wallerstein answered: "As a matter of fact, nowhere" [32. P. 94]. For supporters of the nomothetic method, time and space are principally irrelevant, for they seek to find universal laws that extend beyond time and space. Wallerstein logically explains that due to the irrelevance of the time-space coordinates, nomothetic research can be conducted wherever it is relevant in time and space for researchers, as the data obtained is universally applicable.

However, supporters of the ideographic method are in no better position in relation to time and space. For these scholars, called by Wallerstein 'great particularists', the key question is the choice of what to study. The implications of this approach are similar to the positions of the supporters of the nomothetic method: the subject of research is limited to easily available and applicable data. Somewhat different is the narrative approach of historical sciences, according to Hayden White [33]. Every narrative is in some way 'inserted' in time and space, even when the 'narrated' has the so-called 'timeless meaning or message'.

\section{Different forms of time as a frame of narrativity}

Jan Sokol, in his book Time and Rhythm, states that in human experience captured by language, one can distinguish four meanings of time: a) time as an entity that flows, b) time as a duration, c) time as a measurement, d) time to do something [27. P. 21-24]. Let us add that there is also time defined as change.

Time as passing: everyday human life brings evidence of the unstoppable and irreversible march of time, in which many (new) things come, but also (often forever) go. The general variability of the world was expressed by Heraclitus of Ephesus in his thesis panta rhei. When narration is concerned, it is necessary to make it clear and comprehensible. Even if narration is not structured in time, its logical succession should be identifiable.

Time as duration: life and things around us 'endure'. Some things, in our human perspective, last but briefly, while others last longer and some may even seem everlasting. Unlike the Heraklitean image of the river, the term 'duration' encourages us to believe in the image of a time 'reservoir' (Giddens would say 'container'), in which separate partial durations are as if 'embedded'. Philosophers sometimes define time as a 'way of duration'. Since different things and human lives last for variable periods, time creates, among other things, the so-called 'non-present present'.

Time as measure: according to Sorokin and Merton, in ancient societies, there were diverse, locally differentiated systems of counting and measuring time, which 
depended on the activities the society was engaged in. Modern industrial society established a uniform time-slot pattern of hours, minutes and seconds. In historical narration, the precise definition of time of the story is crucially important for the location of actions in these coordinates is one of the prerequisites for understanding.

Time for something: in the archaic consciousness, time often had certain qualities, which could be 'good' or 'bad', 'favorable' or 'unfavorable'. Ancient Greeks used the notion of kairos as representing favorable moments for action, which should not be missed. The necessity to decide what action is appropriate for what time is something common today too. In the historical reflection, we encounter formulations such as 'moment of decision', 'testing times' or 'fruitful times'.

Time as change: if nothing changed, we could not perceive time. In the ancient worldview, which attributed certain qualities to time, it was recorded only when something happened. If nothing happened, it was as if time stopped. However, there are examples of this tendency in the contemporary thinking. For instance, in some philosophical reflections, the period of normalization in Czechoslovakia in the 1970s - 1980s was called 'timelessness'.

In addition to the mentioned five forms of time which we find in the historical narrative, historical interpretations always include — often implicitly — the relationship between the past that the author describes and the present he lives in. In historiography, everyone finds out that something that once happened in a certain way is not the same something for future generations, and this is not a question of information, knowledge and available methods. George Herbert Mead considered the reconstructive function of thinking as presented in the American pragmatic philosophy: people in the present constantly change concepts and understandings of the past and the future due to new circumstances that bring into new light what already happened or is likely to happen. The acting subject, when being exposed to new experiences, returns to the past, looks at it in a different way and adjusts future behavior and expectations accordingly.

Mead believes that we tend to interpret the past as irrevocable. Therefore, he explained that the past can irrevocable and revocable at the same time. The past is irrevocable for we cannot change things that have already happened. However, their meaning and how they are stored and recalled make the irrevocable and as hypothetical as the future - it is constantly transformed and reformulated into a different past in terms of the present: we cannot say what Caesar or Charlemagne (Charles the Great) will present to people in the next century [25. P. 416].

Various forms of time represent 'frames' to narration, through which it is constructed and understood. Jean Leduc identified three typical characteristics of narrative sequences: (a) organizing the succession of events, (b) integrating into continuation (including beginning and end) and containing chronological points of reference (data or other indicators), (c) presenting a process [24. P. 228]. The interpretation of the time process as a flow presents it as a succession of sequences and causalities. This process takes time, and in the subsequent time it may continue to have influence and consequences. Individual events and sequences need to be 
assembled in the historical interpretation within coordinates of time. Above all, one can consider how events corresponded to the general nature and tendencies of the given time or situation, and whether the phases and stages of the historical development were transformed by it. The idea of frames established a tradition in the sociological thinking represented mainly by Maurice Halbwachs and Erving Goffman.

Halbwachs focuses on how memory works and reproduces in certain social frameworks, through which our memories are formed and evoked [14]. These frameworks, of the temporal, spatial and linguistic nature, are not rigid but dynamic structures created by the elements that represent and organize our memories, including 'landmarks in space and time, historical, geographical, biographical, political concepts, current experience and familiar perspectives' [21. P. 35]. A typical example of the memory framework is the calendar and its organized system of holidays and important events.

Goffman defines frameworks as units of the organized experience [19]. Frameworks enable social actors to locate, perceive, identify and classify the seemingly endless number of events. "One of the functions of the framework is a definition of the ongoing interaction between main and incidental processes, and what eventually should be excluded from further interaction, i.e., what is visible and possible in the given situation but should be ignored" [29. P. 8-9]. Basic frameworks acquired by members of the particular community represent elements of their culture; therefore, what sort of events are 'framed' by us, and what frameworks we use, determines how we see them, think and talk about them.

\section{Variety of time forms}

We mentioned five forms of time in the historical narration - distinct though interconnected time-frames. Now we will focus on the concept of time as duration, which was developed by Fernand Braudel. He believed that in the diversity of times revealed by the historical study, one can distinguish the short time of discrete events - courte durée - related to individual destinies and separate events, and cyclical processes, examples of which are economic cycles ('booms') or (very) long courses of time - longue durée [12. P. 189-215]. Braudel focused on contradictions and tensions between the two poles of time - courte durée and longue durée. Within short periods of time, Braudel considers events that he compares to explosions. The short span of time is 'the most stubborn' and 'the trickiest' — the time of chroniclers and journalists, who record events of everyday life (e.g., fires, railway accidents, grain prices, crime, theatre performances). We encounter this brief course of time in all forms of life - in economics, social sphere, literature, religion, geography and politics. An individual event can be associated with a number of meanings and contexts. Sometimes it is a real testimony of very deep shifts; sometimes it is rather artificially inserted into a play of 'causes' and 'consequences'.

At first glance, the past seems a mass of details. In the late $19^{\text {th }}$ century, along with the significance of authentic documents, a new style of the historical study 
developed - following the history of events through the correspondence of ambassadors or parliamentary debates step by step. This way of writing history, according to Braudel, allowed to describe political history but not economic or social history - of institutions, religions or civilization. Thus, new approaches developed in the $20^{\text {th }}$ century, such a study of economic cycles, which led to the idea of long courses of time. In Braudel's historical works, one can find three different speeds of history [11]: fast movement of chronology (temps individuel in histoire événementielle), a slower but still detectable rhythm of changes in political, cultural and economic systems (temps social in histoire conjoncturelle), the almost unattainable flow of 'geohistory' - history of relationships between man and nature (temps géographique in histoire structurelle); i.e., history as if motionless, of constant repetition, and of ever-returning cycles. Braudel does not consider history in terms of individual action or great personalities, because behind individual actions and decisions, there is a much deeper and slower rhythm of longue durée.

Anthony Giddens was inspired by Braudel's approach to time, but his concept is different. According to Giddens' theory of structuration, every moment of social reproduction includes three interrelated levels of time [17. P. 93]: durée of day-today experience - temporality of immediate experience, the continuous flow of everyday life; Dasein - temporality of 'residence', the course of individual life; longue durée of institutions - 'long duration' of institutional time associated with the development and reproduction of social institutions. Giddens considers time through the prism of the duality of reversible and irreversible time. The term durée serves to describe the repeated elements of social life; Dasein expresses the irreversible flow of human life.

In The Constitution of Society, Giddens provides a diagram explaining that durée stands for the temporality of everyday experience and corresponds to 'reversible time', Dasein - for the temporality of individual life and 'irreversible time', longue durée - the long duration of institutions and 'reversible time' [17. P. 89]. The concept of durée was borrowed by Giddens from Schütz as a definition of routine, repetitive elements, as a permanent time characteristic of an action (such as driving a car or cooking food). The irreversibility of Dasein Giddens relates to the life of individuals as Heideggerian Sein zum Tode. Thus, the reversible time of institutions is the condition and the result of everyday practices.

However, Giddens' understanding of the longue durée was influenced by Foucault. Linking the ideas of the Annales School with Michel Foucault might seem problematic for Foucault's works seem a rejection of the uninterrupted continuity of longue durée. Nevertheless, a certain affinity can be seen due to Foucault's search for differences within continuity of long historical periods [11. P. 43]. Every rupture or new event marks the end of one longue durée and the beginning of another longue durée. Foucault is interested in deviations that distinguish one period from another and provide a longue durée with different characteristics. 


\section{Space}

There are two main theoretical positions on space: substantial and relational. The substantial approach interprets space as the essence of bodily substance; the relational approach - not as an independent entity but as an order of relations formed by interacting objects, i.e., space does not exist outside this system of interactions. Today, space is a key object of social geography, whose beginnings in the $19^{\text {th }}$ century intertwined with the history of sociology. In the Russian sociology, Alexander Filippov especially considered space [6] with great thoroughness and philosophical depth.

Although Giddens seems to be the most famous contemporary author to consider time-space relations, in the early $20^{\text {th }}$ century, Georg Simmel developed a comprehensive theory of the impact of modernity on time and space [26]. Environmental psychologists consider Simmel's theory as predicting some recent theoretical and empirical achievements in social sciences and providing relevant hypotheses on time and space [30. P. 46]. Simmel studied the significance of spatial arrangements and movement through space. He argued that societies often select certain places as symbols of local culture, and the familiarity with these places increases the cohesion of social group. According to Simmel's ecological psychology, pre-industrial or rural cultures experience and organize space in a specific way, while post-industrial or urban cultures foster more abstract forms of spatial experience [23].

Unlike the ecological approach of the Chicago school, David Harvey and Manuel Castells focus not on 'natural' spatial processes, but on how artificial environments reflect social and economic systems of power, which indicates a new emphasis in the study of urbanization and globalization. Harvey emphasizes that urbanism is an aspect of the artifact environment developed by the industrial capitalism [15]. In traditional societies, city and urban places had clear distinctions; today, they are constantly restructured. Castells stresses that the spatial forms of society are interrelated with the general mechanisms of their development [13]. To understand the city, it is necessary to understand the processes of transformation of spatial forms. The urban environment provides numerous symbolic and spatial examples of wider social forces.

Torsten Hägerstrand added spatial components to sociological and economic models of the diffusion of information, arguing that the largest cities become the centers of innovations in the global world [16]. All innovations, such as new ideas and practices, are spread to other urban and even non-urban places from the largest megacities. Hagerstrand's models were applied to urban systems to explain the spatial organization of society. His research helped to make Lund a major innovative center in Sweden and develop the practice of spatial planning. Jeffrey Alexander connects the issue of space with the construction of civil society for it needs a particular urban territory: power belongs to those who 'privatized' this special space [10. P. 98]. Pierre Bourdieu developed a concept of social space as a form of certain relationships or ways of coordination between the states of different 
objects. Social space manifests structure of various types of capital distributed unequally between individual agents and groups in the physical space, which is a projection of social space and objectifies the past and present social relations [4].

Recent research on modernization, space and time show how these factors change mobility [31], influence attitudes to the community and diminish the sense of local community [22]. John Urry showed that instead of the universal space-time coordination and functioning of mobility systems, there is a mobile, flexible system of flows and 'instant time'. However, until recently, sociology has not paid enough attention to the fact that social practices are spatially patterned [5].

Giddens suggested a new approach to time and space in his structuration theory and works on modernity. Distanciation of time and space is a source of modern dynamics. For Giddens, the time-space characteristics of modernity differ greatly from the traditional ones. First, they are independent from each other and became abstract means of measurement and comparison. In the traditional society, the spatial aspect of social life was dominant due to the community's space locality the measurement of time depended on space and natural cycles. In modernity, social systems exist in space and time due to the effective means of communication and transport; therefore, social interaction can be free of local contexts. "The advent of modernity has increasingly torn space and time, establishing relationships with absent 'others' that are remote from any face-to-face interaction" [18. P. 18]. The separation of time and space was a crucial factor of modernity due to disembedding social systems and opening manifold possibilities of change. This provided gearing mechanisms for such an important feature of modernity as rationalized organization. Finally, the notion of history changed as it gained a new impetus for unifying the past: "time and space are recombined to form a genuinely worldhistorical framework of action and experience" [18. P. 21].

The modern political organization of space in the form of nation states provides space with some specificity. The nation state is a political and also spatial form of modern society - with internationally recognized national borders, specific systems of social control, and regional monopolies on the means of violence. Giddens' contribution to the analysis of time and space is extremely important for modernity and presents the system of nation states as a measure of globalization.

\section{Different types of time-space}

Immanuel Wallerstein, who refers to Braudel, claims that historical social sciences must make space-time the main organizing principle of their work. The first step is to recognize the existence of different types of space-time for time and space cannot be analyzed separately: every time has its place and every place has its time; certain types of time and space simply belong to each other. Wallerstein identified five kinds of time-space: episodic-geopolitical, conjunctural-ideological, structural (Wallerstein's episodic-geopolitical, conjunctural-ideological and structural timespaces correspond to Braudel's histoire événementielle, histoire conjoncturelle and histoire structurelle), eternal time-space, transformative time-space [32. P. 114-116]. 
Episodic-geopolitical time-space describes the time and space of events. Every event - of great or minor importance - can become an object of a political or intellectual debate about the time and space associated with it. For instance, when and where (in what episodic-geopolitical time-space) the Russian Revolution took place - there are thousands of books about this time-space.

Considering the reason why historical social sciences can hardly reach consensus on the episodic-geopolitical time-space, Wallerstein explains that historical events are usually (explicitly or implicitly) included in different, often contradictory conjunctural-ideological time-spaces. For instance, 1991, when the USSR ceased to exist as a state, marks the end of a certain political-ideological movement (from 1917 to 1989 in the Eurasian space), or the end of the former Russian empire, or the collapse of the last great imperial structure (then the considered time period is 1450-1991, and the space consists of Europe and the world), or the collapse of a certain development movement on the periphery and semi-periphery (referred to as the global South in opposition to the developed global North).

The reason why there is so much disagreement about the conjuncturalideological space-time, is that there is no consensus about structural time-space. Debates on whether the end of the Soviet Union is connected with the fall of communism, the demise of the European empires or the collapse of development schemes on the periphery and semi-periphery, express the evaluation of the historical system in which the cyclically-ideological time-space should be located. Theories present different options: (a) It can be understood as a part of the historical system of the capitalist world economy, which covers the period from 1450 and is located in the expanding space with the center in Western Europe and North America. (b) It can be seen as a part of the modernizing world since 1000 AD. (c) It can be included in the framework of the industrialized world since the late $18^{\text {th }}$ century. (d) There is a structural relation to the European culture and tensions between Rome and the 'East'.

There are also discussions about eternal time-space (Wallerstein's concept is influenced by Sorokin's idea of three levels of the social-cultural time inspired by medieval philosophers - tempus (time), aevum (age) and aeternitas (eternity) [28. P. 215]) representing a kind of antithesis to structural time-space and a premise of nomothetic social sciences. When Adam Smith refers to the natural 'inclination' of mankind to run trade and craft, he finds this general human inclination in eternal time-space. Therefore, the collapse of the USSR can be considered as an inevitable event due to the attempt to oppose natural human affections.

Finally, there is transformative time-space (Wallerstein's concept reminds Georges Gurvitch's concept of explosive time: extremely different and often divergent times often compete and are in conflict with each other; Gurvitch developed a typology of eight social times depending on their duration, way of pulsation and rhythm of movement [20. P. 31-33]; explosive time means the maximum degree of discontinuity associated with the sudden commencement of a new future). In this case, social sciences ask the question of whether and how there 
are historical transitions, revolutions or moments of decision. Transformative timespace is associated with structural time-space, because the former is possible only when there are developmental structures that lead to uncertain outcomes.

All these questions Wallerstein raises without claiming that he can answer them. One reason why he places such an emphasis on issues of time-space is that he believes that we live in transformative time-space at the end of the long structural time-space of the modern world system [32. P. 117]. Thus, we are at the point of choosing historical possibilities with intellectual and at the same time political aspects. There is no certainty in our decision-making, except that every decision will have significant consequences.

To conclude, we have to admit that descriptions and explanations of historical events is a 'terrain' of time-space coordinates linked to philosophical assumptions. As far as historical science is concerned, many historical narrators fail to reflect these assumptions and are not aware of the extent to which 'the narrated story' can be shaped by the chosen 'time-space'. For many historical treatises, these frameworks are somewhat concealed or barely realized. The deconstruction of hidden assumptions and concealed frameworks should be a task of historical sociology.

\section{References}

[1] Artemov V.A. A sketch of the sociological concept of social time. Sotsiologicheskie Issledovaniya. 2013; 11 (In Russ.).

[2] Babayan I.V. Social time: An issue and approaches. Izvestiya Saratovskogo Universiteta. Serija: Sotsiologiya, Politologiya. 2011; 11 (2) (In Russ.).

[3] Belyaev M.A. On social time in terms of methodology. Vestnik Voronezhskogo Universiteta. Serija: Filosofiya. 2011; 1 (In Russ.).

[4] Bourdieu P. Sociology of Social Space. Saint Petersburg; 2005 (In Russ.).

[5] Titarenko L.G. Paradigms and Turns in Contemporary Sociology. Minsk; 2018 (In Russ.).

[6] Filippov A.F. Sociology of Space. Saint Petersburg; 2008 (In Russ.).

[7] Šubrt J. The concept of social time in sociology — a promising approach or a theoretical impasse? Sotsiologicheskie Issledovaniya. 2015; 4 (In Russ.).

[8] Šubrt J. Antinomies, Dilemmas and Discussions in Contemporary Sociological Thought: Essays on Social Theory. Moscow; 2018 (In Russ.).

[9] Šubrt J. Historical Processes, Social Changes, Modernization in the Sociological Perspective. Moscow; 2017 (In Russ.).

[10] Alexander J. Contradictions: The uncivilizing pressures of space, time, and function. Soundings. 2000; 16.

[11] Baert P. Time, Self and Social Being: Temporality Within a Social Context. Avebury; 1992.

[12] Braudel F.Geschichte und Sozialwissenschaften — Die 'longue durée'. Hans-Ulrich Wehler (Ed.). Geschichte und Soziologie. Köln; 1972.

[13] Castells M. The City and the Grassroots: A Cross-cultural Theory of Urban Social Movements. Berkeley; 1983.

[14] Halbwachs M. Les cadres sociaux de la mémoire. Paris; 1994.

[15] Harvey D. Social Justice and the City. Athens; 1973. 
[16] Hägerstrand T. Space, time and human conditions. Karlqvist A., Lundqvist L., Snickars F. (Eds.). Dynamic Allocation of Urban Space. Lexington; 1975.

[17] Giddens A. Die Konstitution der Gesellschaft: Gründzige einer Theorie der Strukturierung. Frankfurt-New York; 1988.

[18] Giddens A. The Consequences of Modernity. Stanford; 1990.

[19] Goffman E. Frame Analysis: An Essay on the Organization of Experience. London-New York; 1974.

[20] Gurvitch G. The Spectrum of Social Time. Dordrecht; 1964.

[21] Kvasničková A. Náboženstvo ako kolektívna pamät': prípad Slovenska a Čiech. Bratislava; 2005.

[22] Lewicka M. On the varieties of people's relationship with places: Hummon's typology revised. Environment and Behavior. 2011; 43.

[23] Lechner F. Simmel on social space. Theory, Culture and Society. 1991; 8.

[24] Leduc J. Historici a čas: Koncepcie, otázky, diela. Bratislava; 2005.

[25] Mead G. H. Movements of Thought in the Nineteenth Century. Chicago; 1936.

[26] Simmel G. The sociology of space. Frisby D., Featherstone M. (Eds.). Simmel on Culture. London; 1997.

[27] Sokol J. Čas a rytmus. Praha; 1969.

[28] Sorokin P.A. Sociocultural Causality, Space, Time: A Study of Referential Principles of Sociology and Social Science. New York; 1964.

[29] Šrubař, I. Sociální jednání a sociální řád. S-obzor: Čtvrtletník pro kritickou sociologii. 1993; 4.

[30] Sullivan D., Sheridan A.S., Diefendorf J. Simmel's time-space theory: Implications for experience of modernization and place. Journal of Environmental Psychology. 2015; 41.

[31] Urry J. Mobilities. Cambridge, MA: Polity Press; 2007.

[32] Wallerstein I. Der ZeitRaum der Weltsystemanalyse. Bögehold D. (Ed.). Moderne Amerikanische Soziologie. Stuttgart; 2000.

[33] White H. Metahistory: The Historical Imagination in Nineteenth-Century Europe Baltimore; 1973.

\title{
Размерность времени и пространства в социологии*
}

\author{
И. Шубрт ${ }^{1}$, Л.Г. Титаренко ${ }^{2}$ \\ ${ }^{1}$ Карлов университет \\ У Криже, 8, Прага 5, 15800, Чехия \\ ${ }^{2}$ Белорусский государственный университет \\ просп. Независимости 4, Минск, 220030, Беларусь \\ (e-mail: Jiri.Subrt@ff.cuni.cz; larissa@bsu.by)
}

\begin{abstract}
Современная социология существенно изменила концепцию пространства и времени. По мнению И. Валлерстайна, время и пространство представляют собой реальность, которой социология давно пренебрегает. Обратную ситуацию мы наблюдаем в исторических науках, где преобладает, как констатирует Х. Уайт, нарративный подход, а также в исторической социологии. Статья фокусируется на теме времени и пространства как «рамках», в которые всегда встраивается исторически ориентированная интерпретация. Время может трактоваться по-разному — как поток, продолжительность, скорость, момент, подходящий для некоторых действий и изменений.
\end{abstract}

\footnotetext{
* (С Шубрт И., Титаренко Л.Г., 2020

Статья поступила 16.05.2020 г. Статья принята к публикаџии 30.08.2020 г.
} 
Различные формы времени представляют собой разные «рамки», в которых объяснение произошедших исторических событий становится понятным. «Рамки», в которые мы помещаем событие, определяют его восприятие и осмысление. На эту рефлексию существенно повлиял Ф. Бродель, выделивший три уровня исторического времени. Пространство интерпретируется современными авторами, как правило, в реляционном смысле - как порядок отношений, образуемых взаимодействующими объектами, или отношений как способов координации состояний предметов исследования. Проблематикой времени и пространства сегодня занимается социальная география, наработки которой отчасти заимствует социология - как показал Э. Гидденс, преимущественно при рассмотрении вопросов модернизации и глобализации. Социологическая концепция пространства-времени была разработана И. Валлерстайном, который выделяет пять типов пространствавремени: эпизодически-геополитическое, конъюктурно-идеологическое, структурное, вечное и преобразующее - каждое открывает особые перспективы для анализа конкретных исторических событий. Одна из причин, почему Валлерстайн делает акцент на пространстве-времени, состоит в том, что, по его мнению, мы живем в преобразующем пространстве-времени, которое наступает в конце длительного периода структурного пространства-времени современной мировой системы. Мы находимся в точке столкновений вариантов исторического выбора, полной неопределенности - за исключением того, что каждый сделанный нами шаг будет иметь серьезные последствия.

Ключевые слова: социологическая теория; историческая социология; история; пространство-время; развитие; циклы; модернизация; глобализация; Валлерстайн, Гидденс 